\title{
GENOTYPES OF ESBL PRODUCING ESCHERICHIA COLI AND KLEBSIELLA PNEUMONIAE IN RELATION TO RESISTANCE TO ANTIMICROBIAL DRUGS
}

\author{
Ana Kaftandzieva, Elena Trajkovska-Dokic, Vesna Kotevska, Zaklina Cekovska, \\ Gordana Jankoska
}

Institute of Microbiology and Parasitology, Medical Faculty, Ss. Cyril and Methodius University, Skopje, R. Macedonia

Corresponding Author: Ana Kaftandzieva, Institute of Microbiology and Parasitology, Medical Faculty, Ss Cyril and Methodius University 50 Divizija br. 6, 1000 Skopje, R. Macedonia, Tel: + 389 (0)2 31098 29, Fax: + 389 (0)2 3214317 , E-mail: akaftandzieva@yahoo.com

\begin{abstract}
The aim of the study was to evaluate the association of drug resistance with $\beta$-lactamase gene types in ESBL positive E. coli and Klebsiella pneumoniae-Kp.

Material and methods: A total of 251 ESBL-positive E. coli and $\mathrm{Kp}$ isolates obtained from urine, tracheal aspirate, wound swab and blood from patients hospitalised at the University Clinics in Skopje were detected using the ESBL set and automated Vitek 2 system. Vitek was also used for susceptibility testing (determination of MIC of 17 antimicrobial agents). Multiplex PCR was used to identify genes for different types of ESBLs in a 100 randomly selected, ESBL positive strains.

Results: More of the 87 ESBL typeable isolates $(61 \%)$ harbour two or more bla genes and the frequency of antibiotic resistance was high in these isolates, compared to those with a single gene. Isolates with $\geq 3$ genes were highly resistant to beta-lactams and non-beta lactams used. The degree of resistance to $3^{\text {rd }}$ generation cephalosporins was also high in these isolates (MIC $\geq 64$ ). More of the ESBL-positive isolates showed higher resistance to cefotaxime than to ceftazidime.

Conclusion: Identification of the genes is necessary for the surveillance of their transmission in hospitals. Surveillance of antibiotic resistance patterns are crucial to overcome the problems associated with ESBLs.
\end{abstract}

Key words: ESBL, Escherichia coli, Klebsiella pneumoniae, antibiotic resistance.

\section{Introduction}

Beta-lactam antibiotics are the most widely used antibiotics in treating bacterial infections. The production of $\beta$-lactamases is an important mechanism of resistance to $\beta$-lactams. The most common $\beta$-lactamases are the plasmid-encoded TEM and SHV enzymes. Derivatives of these enzymes showed an enlarged ability for antibiotics destruction. Extended-spectrum beta-lactamases (ESBLs) were first described in the 1980s and they have been detected in the Klebsiella species and later in E. coli and other genera of the Enterobacteriaceae family. ESBLs have the ability to hydrolyze all cephalosporins and monobactams, but are inhibited by $\beta$-lactamase inhibitors, such as clavulanic acid $[1,2]$.

ESBLs are undergoing continuous mutation, causing the development of new enzymes showing expanded substrate profiles. To date, there are over 212 derivatives of TEM betalactamases and more than 178 derivatives of SHV $\beta$-lactamases. In recent years, several new ESBLs of non-TEM, non-SHV types have emerged, such as enzymes of the CTX-M (148 variants so far), PER, VEB etc. Particularly, CTX-M type enzymes increased in E. coli and 
$K$. pneumoniae isolates from Spain, the United Kingdom and Russia [3-5].

ESBL are an increasingly important cause of transferable multidrug resistance in Gramnegative bacteria throughout the world. These bacteria have spread rapidly and have become a serious threat to human health worldwide. Since ESBL distribution has been shown to differ among countries, monitoring of the prevalence and the types of ESBLs may contribute to defining the breadth of the problem and appropriate therapeutic options [6-8].

In Europe, the prevalence of these organisms varies from country to country $(3 \%$ in Sweden to $34 \%$ in Portugal) [9].

A first study on this matter has been performed in University Clinics in Skopje. Although $E$. coli strains were more frequently isolated than $K$. pneumoniae strains, the production of ESBLs was more often present in $K$. pneumoniae. The prevalence of ESBL-producing $E$. coli and $K$. pneumoniae had the means of $15.7 \%$ and $31 \%$, respectively. There was a difference in the prevalence of ESBL-producing E. coli and K. pneumoniae in surgical clinics compared to that in clinics of internal medicine. ESBL-positive $K$. pneumoniae strains were more prevalent in surgery clinics compared to ESBL-positive $E$. coli strains [10, 11]. Detection and distribution of bla genes in $E$. coli and $K$. pneumoniae isolates have also been made. A difference between strains harbouring two or more genes $(61 \%)$ compared to those with a single gene (39\%) has been detected. The equal number of strains of $E$. coli and $K$. pneumoniae possessed a single gene, but there was a statistically significant difference in the presence of bla $\mathrm{TEM}_{\mathrm{TEM}}$ and bla $\mathrm{SHV}_{\mathrm{SH}}$ between $E$. coli and $K$. pneumoniae $(\mathrm{p}=0,007)$. Considering the combination of the two genes, bla $\mathrm{TEM}+$ bla $_{\text {SHV }}$ was the most common one $(16 \%)$. Eight strains of $E$. coli and 4 strains of $K$. pneumoniae harbour 3 genes. Only 7 strains of $K$. pneumoniae $(8 \%)$ and none of $E$. coli harbour 4 beta-lactamase genes [12]. The same E. coli and K. pneumoniae isolates were used in the present study.

The aim of the study was to evaluate the association of drug resistance with $\beta$-lactamase gene types in ESBL positive E. coli and Klebsiella pneumoniae.

\section{Material and methods}

\section{Material}

\section{Bacterial strains}

\section{a. Strains obtained from clinical specimens}

A total of 1207 consecutive non-repeat isolates of E. coli (804 isolates) and Klebsiella pneumoniae (Kp) (403 isolates) were obtained from different clinical specimens (urine, tracheal aspirate, wound swab, blood, etc.) over a one-year period from patients hospitalised at the University Clinics (UC) in Skopje. The isolates were identified on the basis of conventional microbiological procedures. Detection of susceptibility of the isolates to various antimicrobial agents was done by the standard disc diffusion method on Mueller-Hinton agar (Oxoid, UK), following the zone size criteria as recommended by the Clinical and Laboratory Standards Institute (CLSI).

A confirmatory test for phenotypic detection of ESBLs (double disc assay, ESBL set, Mast Diagnostic) and Vitek 2 automated system for identification and confirmation of ESBL-production was performed on all strains with reduced susceptibility to third generation cephalosporins. Of 804 isolates, 126 (15.7\%) isolates of $E$. coli were found to be ESBL producers and out of 403 isolates, 125 (31\%) isolates of Klebsiella pneumoniae were ESBL producers. These strains were positive to at least one pair of cephalosporin/cephalosporin-clavulanic acid of the ESBL set and confirmed by Vitek. Of 251 ESBL-positive strains, 100 ESBL positive strains (E. coli-52 and K. pneumoniae-48) were randomly selected to detect the presence of genes.

\section{b. Control strains}

For both phenotypic methods and for multiplex PCR, two ATCC strains (American Type Culture Collection, USA) have been used: $K$. pneumoniae ATCC 700603 as positive control and Escherichia coli ATCC 25922 as negative control.

Methods

1. Automated susceptibility testing using Vitek 2 compact sistem (bioMerieux, France)

MIC (minimal inhibitory concentration) of 17 antimicrobial agents: ampicillin, amoxicillin-clavulanic acid, piperacillin, piperacillin- 
tazobactam, cefazolin, cefoxitin, cefotaxime, ceftazidime, cefepime, imipenem, amikacin, gentamicin, ciprofloxacin, norfloxacin, tetracycline, nitrofurantoin and cotrimoxazole was determined. MIC values were interpreted as S, I and R by reference to CLSI breakpoints.

\section{Multiplex PCR for different bla genes}

Purification of whole DNA was prepared from cultured cells by the method of thermal lyses. Multiplex PCR was performed using 2 sets of primers, each targeting different regions. The first multiplex assay (named SET I) was designed to detect TEM, SHV, CTX-M IV group and OXA $\beta$-lactamase encoding genes, and the second assay (named Set II) was designed to detect the CTX-M I group, CTX-M II group and DHA encoding genes (http://www. Lahey.org/studies/webt.asp). Both PCR reactions were performed under identical conditions. All of the Set I and SET II assays produced single or multiplexed products of the pre- dicted sizes. The methods have been described previously [12-15].

\section{Statistical methods}

Fisher exact test, Yates corrected and the difference between proportions were applied to see the significance of difference between the various genes in ESBL-producing $E$. coli and $K$. pneumoniae. Comparison of proportion was done by using the chi square test with appropriate correction for antibiotic resistance among groups. $p \leq 0.05$ was considered significant.

\section{Results}

Only the positive results obtained by multiplex PCR (isolates harbouring single or more beta-lactamase genes - 87) were compared to the results of Vitek 2 (MIC values to beta-lactam and non-beta lactam antibiotics). The resistant rates of different ESBL types to beta-lactam and non-beta lactam antibiotics were shown on Table 1.

Table 1

ESBL-positive strains: resistance to potentially active drugs according to gene type

\begin{tabular}{|c|c|c|c|c|c|c|c|}
\hline Antibiotics & $\begin{array}{c}\text { TEM } \\
(\mathrm{n}=14)\end{array}$ & $\begin{array}{c}\text { SHV } \\
(\mathrm{n}=17)\end{array}$ & $\begin{array}{l}\text { CTXM } \\
(\mathrm{n}=3)\end{array}$ & $\begin{array}{c}\text { TEM+SHV } \\
(\mathrm{n}=14)\end{array}$ & $\begin{array}{c}\text { TEM+CTXM } \\
\text { SHV+CTXM } \\
(\mathrm{n}=9+2)^{*}\end{array}$ & $\begin{array}{c}\text { OXA+CTXM } \\
(n=9)\end{array}$ & $\begin{array}{c}\geq 3 \\
\text { genes } \\
(\mathrm{n}=19)\end{array}$ \\
\hline \multicolumn{8}{|c|}{ Resistance \% } \\
\hline Ampicillin & 100 & 100 & 100 & 100 & 100 & 100 & 100 \\
\hline AMC & 35.7 & 64.7 & 0 & 64.3 & 0 & 11.1 & 94.7 \\
\hline Piperacillin & 100 & 100 & 100 & 100 & 100 & 100 & 100 \\
\hline PIP/TAZ & 28.6 & 35.3 & 33,3 & 50 & 9 & 0 & 68.4 \\
\hline Cefazolin & 100 & 100 & 100 & 100 & 100 & 100 & 100 \\
\hline Cefoksitin & 21.4 & 41 & 0 & 14.3 & 0 & 11.1 & 21 \\
\hline Cefotaxime & 78.6 & 88.2 & 100 & 92.8 & 100 & 100 & 100 \\
\hline Ceftazidim & 85.7 & 53 & 66,6 & 28.6 & 36.4 & 22.2 & 89.5 \\
\hline Cefepime & 28.6 & 41 & 33,3 & 42.8 & 45.5 & 22.2 & 63 \\
\hline Imipenem & 0 & 0 & 0 & 0 & 0 & 0 & 0 \\
\hline Amikacin & 7 & 23.5 & 100 & 0 & 0 & 0 & 26.3 \\
\hline Gentamicin & 71.4 & 76.5 & 100 & 64.3 & 45.5 & 100 & 84.2 \\
\hline Ciprofloxacin & 50 & 47 & 100 & 42.8 & 54.5 & 88.8 & 68.4 \\
\hline Norfloxacin & 57.1 & 53 & 100 & 50 & 63.6 & 88.8 & 78.9 \\
\hline Tetracyclin & 64.3 & 58.8 & 100 & 71.4 & 45.5 & 77.7 & 78.9 \\
\hline Nitrofurantoin & 7 & 17.6 & 0 & 14.3 & 18 & 0 & 31.6 \\
\hline SXT & 64.3 & 58.8 & 66,6 & 78.6 & 45.5 & 66.6 & 52.6 \\
\hline
\end{tabular}

* SHV+CTX-M E. coli- $0 ;$ K. pneumoniae-2

AMC - amoxicillin-clavulanic acid; PIP/TAZ - piperacillin/tazobactam; SXT - cotrimoxazole

All ESBL-positive isolates were resistant to ampicillin, piperacillin and cefazolin and none of them was resistant to imipenem. Among combinations of $\beta$-lactam- $\beta$-lactamase inhibitor, the activity of amoxicillin-clavulanate and piperacillin-tazobactam varied between different types of ESBL enzymes. Isolates producing 3 and more enzyme types were characterized by the 
highest degree of resistance to AMC compared to those with single and two genes. This difference is statistically significant. In a case of PIP/TAZ this difference is not statistically significant $(\mathrm{p}>0.05)$. Although ESBLs were not active against cefoxitin, in vitro, different ESBL types showed resistance between $0-41 \%$ (isolates with CTX-M alone or associated with TEM and SHV were not resistant; strains with SHV showed the highest resistance of $41 \%$, possibly due to overexpression of chromosomal AmpC $\beta$-lactamase). Considering cephalosporins, isolates with $\geq 3$ genes were highly resistant to cefotaxime, ceftazidime and cefepime compared to the isolates with a single or two genes. This difference is statistically significant. Cefepime showed the best in vitro activity (except isolates with two enzyme types, such as TEM+SHV and TEM+CTX-M, to which cefepime was less active than ceftazidime). MICs of 64 of ceftazi- dime and cefotaxime were $48.3 \%$ and $79.3 \%$ of ESBL-positive isolates, respectively. Considering aminoglycosides, amikacin showed better in vitro activity than gentamycin, regardless of ESBL type (except isolates with CTX-M, which were $100 \%$ resistant to both aminoglycosides). There were no big differences in the resistance to fluoroquinolones between differrent enzyme types. Isolates with two types of beta-lactamases (OXA+CTX-M) showed the highest resistance of $88.8 \%$ The resistance to nitrofurantoin was lower compared to tetracycline and co-trimoxazole. Isolates with 3 and more ESBL types showed the highest resistance to nitrofurantoin (31.6\%). There was no difference in the resistance to cotrimoxazole among various types of ESBLs $(p=0.19)$.

MICs of cefotaxime and ceftazidime were analysed, due to the fact that they are good ESBL substrates and due to their clinical relevance (Tables 2 and 3).

Table 2

Distribution of bla genes of ESBL producing E. coli and K. pneumoniae in various ranges of MIC of cefotaxime in relation to genotypes

\begin{tabular}{|c|c|c|c|c|c|c|c|}
\hline $\begin{array}{l}\text { Enzyme type } \\
\quad(\mathrm{n}=87)\end{array}$ & $<2$ & 2 & 4 & 8 & 16 & 32 & \\
\hline & $\mathbf{S}$ & \multicolumn{5}{|c|}{ I } & $\mathbf{R}$ \\
\hline TEM & & \multirow{3}{*}{2} & 1 & 5 & 1 & \multirow{3}{*}{2} & 7 \\
\hline SHV & & & & \multirow[t]{2}{*}{2} & \multirow[t]{2}{*}{3} & & 8 \\
\hline CTX-M & & & & & & & 3 \\
\hline TEM+SHV & & & & 1 & & 1 & 12 \\
\hline TEM+CTX-M & & & & & & & 9 \\
\hline SHV+CTX-M & & & & & & & 2 \\
\hline OXA+CTX-M & & & & & & & 9 \\
\hline$\geq 3$ genes & & & & & & & 19 \\
\hline \multirow[t]{2}{*}{ Total } & 0 & 2 & 1 & 8 & 4 & 3 & \multirow[t]{2}{*}{$69(79.3 \%)$} \\
\hline & & & & $7 \%$ & & & \\
\hline
\end{tabular}

From Table 2 it can be seen that MIC values of cefotaxime were different according to the enzyme type. A total of 18 isolates (21\%) had MIC values for cefotaxime between 2-32 $\mathrm{mg} / \mathrm{L}$, and according to the breakpoints could be interpreted as intermediate susceptible. MIC $\geq 64$ was detected in $79.3 \%$ of ESBLpositive isolates. There was a statistically significant difference between the percent of isolates with MIC $\geq 64$ and MIC $<64(p=0.0000)$.
Sixteen isolates which possessed a single gene (16/18) according to the MIC values were intermediate susceptible and $18(18 / 69)$ were resistant. Statistical analysis (difference between two proportions) showed a statistically signifycant difference between these two groups $(\mathrm{p}<0.001)$. This means that higher percent of the isolates with a single gene were intermediate susceptible. If the same statistical analysis was performed to detect the differrence between the isolates with two and more 
genes which were intermediate susceptible (2/18) and resistant (51/69), it could be concluded that between these two groups of isolates a statisti- cally significant difference existed $(\mathrm{p}<0.001)$. A higher number of isolates with two and more genes were resistant to cefotaxime with MIC $\geq 64$.

Table 3

Distribution of bla genes of ESBL producing E. coli and $K$. pneumoniae in various ranges of MIC of ceftazidime in relation to genotypes

\begin{tabular}{|c|c|c|c|c|c|c|c|}
\hline $\begin{array}{l}\text { Enzyme type } \\
\quad(\mathrm{n}=87)\end{array}$ & $<2$ & 2 & 4 & 8 & 16 & 32 & $\geq 64$ \\
\hline & $\mathbf{S}$ & \multicolumn{5}{|c|}{ I } & $\mathbf{R}$ \\
\hline TEM & 2 & 1 & & 2 & 2 & & 7 \\
\hline SHV & 1 & 3 & & & 7 & & 6 \\
\hline CTX-M & & & & & 1 & & 2 \\
\hline TEM+SHV & & & 4 & & 6 & & 4 \\
\hline TEM+CTX-M & & 1 & & & 5 & 1 & 2 \\
\hline SHV+CTX-M & & & & & 2 & & \\
\hline OXA+CTX-M & & 2 & & 4 & 1 & & 2 \\
\hline$\geq 3$ genes & & & & & & & 19 \\
\hline \multirow[t]{3}{*}{ Total } & 3 & 7 & 4 & 6 & 24 & 1 & \multirow{3}{*}{$42(48.3 \%)$} \\
\hline & $\begin{array}{c}3 \\
(3,4 \%)\end{array}$ & \multicolumn{5}{|c|}{$42(48.3 \%)$} & \\
\hline & \multicolumn{6}{|c|}{$45(51.7 \%)$} & \\
\hline
\end{tabular}

From Table 3 it can be seen that MIC values for ceftazidime were different according to the enzyme type. In 45 isolates $(52 \%)$ MIC values for ceftazidime were less than 64 . In 42 of them, MIC varied between $2-32 \mathrm{mg} / \mathrm{L}$, which according to the breakpoints can be interpreted as intermediate susceptible. For the remaining three isolates, MIC values were less than 2, and they can be interpreted as susceptible. MIC for ceftazidime $\geq 64$ were detected in 42 of ESBLpositive isolates $(48.3 \%)$. There was no statistically significant difference between the percentage of isolates with MIC $\geq 64$ and MIC $<64$ $(\mathrm{p}=0.75)$.

Using a statistical method (difference between two proportions), isolates with a single gene, which were intermediate susceptible $(16 / 42)$ and resistant (15/42), were analysed. No statistically significant difference between those two groups was detected $(p=0.82)$. Comparing the $\mathrm{MIC}_{\mathrm{CAZ}}$ in strains with two genes which were intermediate susceptible $(26 / 42)$ to those which were resistant $(8 / 42)$, a statistically significant difference was noticed $(\mathrm{p}=0.0001)$. If the same statistical analysis was performed to detect the difference between the isolates with one and two genes which were intermediate susceptible (42/42) and resistant
$(23 / 42)$, it can be concluded that between these two groups of isolates a statistically significant difference existed $(p=0.0000)$. This means that a higher percentage of the isolates with one and two genes were intermediate susceptible to ceftazidime. Compared to the previous, all 19 isolates with $\geq 3$ genes were highly resistant to ceftazidime with $\mathrm{MIC} \geq 64$.

More of the ESBL-positive isolates showed a higher resistance to cefotaxime than to ceftazidime. This difference is statistically significant $(\mathrm{p}=0.001)$.

\section{Discussion}

The emergence of ESBL-producing organisms seems to be the result of complex interactions between the type of ESBL, the genetic background of the strain and selective pressures existing in ecologic niches. Heavy antibiotic use (especially the third generation cephalosporins) is one of the selective pressures and a risk factor for the acquisition of ESBL-producing organisms. Therefore, clinicians should be familiar with the clinical importance of these enzymes and potential strategies for dealing with them. The correct detection of ESBL-producing micro-organisms is a challenge for the laboratories, requiring not only phenotypic tests, 
but also genotypic tests for all genes associated with $\beta$-lactamase production [16]. Testing both ceftazidime and cefotaxime is an effective choice for ESBL screening [17]. In fact, CTXM-type enzymes may be undetected by screening with ceftazidime alone, whereas a few TEM-type ESBL enzymes can be lost by using cefotaxime alone. Susceptibility is multifactorial, depending on ESBL substrate specificity, production of additional $\beta$-lactamases and changes of outer membrane permeability $[4,18]$.

In our study ESBL-producing bacteria maintained susceptibility to imipenem. Cefoxitin is active against ESBLs in vitro, except when faced with alterations in permeability or the hyperproduction of cefaminases or AmpC $\beta$-lactamases coexisting with the ESBL, in which case the isolate proves itself resistant to this antibiotic [19]. In our study different ESBL types showed a resistant rate between $0-41 \%$. The frequency of antibiotic resistance was high in those isolates of Klebsiella spp. which had both TEM and SHV genes, but they were statistically significant for antibiotic amoxicillin/clavulanic acid only. These isolates also had elevated MIC for cephotaxime and ceftazidime [20]. Beta-lactamase inhibitors such as clavulanate and tazobactam are comparably good inhibitors of SHV and TEM enzymes and piperacillin/tazobactam seems to have a better prospect than other inhibitor combinations against isolates with TEM derivatives enzymes [16]. In our study isolates producing 3 and more ESBL types were characterized by the highest degree of resistance to AMC compared to those with single or two genes. This difference is statistically significant. In the case of PIP/TAZ this difference is not statistically significant $(p>$ 0.05 ). Isolates with $\geq 3$ genes were highly resistant to cefotaxime, ceftazidime and cefepime compared to the isolates with single or two genes. This difference is statistically signifycant. MICs of 64 of ceftazidime and cefotaxime were $48.3 \%$ and $79.3 \%$ of ESBL-positive isolates, respectively. Cefepime showed the best in vitro activity (except isolates with two ESBL types, such as TEM+SHV and TEM+CTX-M, where cefepime was less active than ceftazidime). Although the hydrolytic capacity of the ESBL enzymes against this antibiotic is variable, its use is not recommendable because of failures described in the past [21]. In our study amikacin was more active than gentamicin against all ESBL-types. Some studies have indicated that amikacin is a valuable option for treatment [6]. There were no big differences in the resistance to fluoroquinolones between differrent types of ESBLs. The highest resistance of $88.8 \%$ was shown in isolates with two types of ESBLs (OXA+CTX-M). The resistance to nitrofurantoin was lower compared to tetracycline and co-trimoxazole. Isolates with 3 and more ESBL types showed the highest resistance to nitrofurantoin $(31.6 \%)$. Cotrimoxazole is not really useful unless an antibiogram is made. Hadziyanis et al. found no connection between the presence of ESBLs and resistance to cotrimoxazole (22). In our study there was no difference in the resistance to cotrimoxazole among various types of ESBLs $(p=0.19)$.

In short, carbapenems prove to be crucial for preventing and treating life-threatening nosocomial infections. It is therefore mandatory to maintain the clinical efficacy of carbapenems (imipenem, ertapenem, meropenem, doripenem), which have become antimicrobial drugs of last resort. In the case of non-life-threatening infections and in non-outbreak situations, it is not necessary to administer carbapenems. The heavy use of carbapenems may, in fact, favour the selection of Stenotrophomonas maltophilia (a species naturally resistant to these drugs) [4]. Carbapenem-resistant Enterobacteriaceae have been reported worldwide as a consequence largely of acquisition of carbapenemase genes. It is notable that $K$. pneumoniae isolates producing carbapenemases and different enterobacteria encoding metallo- $\beta$-lactamases have recently been detected in the Mediterranean area [23-25].

\section{Conclusion}

It can be concluded that ESBL-producing $E$. coli and $K$. pneumoniae had elevated MIC for cephotaxime and ceftazidime. More of the 87 ESBL typeable isolates (61\%) harbour $\geq 2$ beta-lactamase genes and the frequency of antibiotic resistance was high in those isolates, compared to those with a single gene. The genotypic methods help us to confirm the genes responsible for ESBL production. The correct identification of the genes involved in ESBLmediated resistance, as well as judicious usage 
of extended-spectrum cephalosporins, periodic surveillance of antibiotic resistance patterns and infection control measures are crucial to overcome the problems associated with ESBLs.

\section{REFERENCE}

1. Bradford PA. Extended-spectrum $\beta$-lactamases in the $21^{\text {st }}$ century: characterization, epidemiology and detection of this important resistance threat. Clin Microbiol Rev. 2001; 14: 933-951.

2. Dashti AA, Jadaon MM, Habeeb FM. Can we rely on one laboratory test in detection of extended-spectrum $\beta$-lactamases among Enterobacteriaceae? An evaluation of the Vitek 2 system and comparison with four other detection methods in Kuwait. J Clin Pathol. 2009; 62: 739-742.

3. Lal K, Kapil A, Das BK, Sood S. Occurrence of TEM $\&$ SHV gene in extended spectrum $\beta$-lactamases (ESBLs) producing Klebsiella sp. Isolated from tertiary care hospital. Indian J Med Res. 2007; 125: $173-178$.

4. Luzaro F, Mezzatesta M, Mugnaioli C, Perilli M, Stefani S, Amicosante G, Rossolini GM, Toniolo A. Trends in production of extended-spectrum $\beta$-lactamases among Enterobacteria of medical interest: report of the second Italian nationwide survey. J Clin Microbiol. 2006; 44: 1659-1664.

5. www. lahey clinic.org, last modified, august 2013.

6. Spanu T, Luzzaro F, Perilli M, Amicosante G, Toniolo A, Fadda G. Occurrence of extended-spectrum $\beta$-lactamases in members of the family Enterobacteriaceae in Italy: implications for resistance to $\beta$-lactams and other antimicrobial drugs. Antimicrob Agents Chemother. 2002; 46: 196-202.

7. Harada S, Ishii Y, Yamaguchi K. Extended-spectrum $\beta$-lactamases: Implications for the clinical laboratory and therapy. Korean J Lab Med. 2008; 28: 401-12.

8. Oliveira CF, Salla A, Lara VM, Rieger A, Horta JA, Alves SH. Prevalence of extended-spectrum beta-lactamases-producing microorganisms in nosocomial patients and molecular characterization of the SHV type isolates. Brasilian J Microb. 2010; 41: 278-282.

9. Canton R, Novais A, Valverde A, Machado E, Peixe L, Baquero F, Coque TM. Prevalence and spread of extended-spectrum $\beta$-lactamase-producing Enterobacteriaceae in Europe. Clin Microbiol Infect. 2008; 14: 144-153.

10. Kaftandzieva A, Kotevska V, Jankoska G, KjurcikTrajkovska B, Cekovska Z, Petrovska M. Extendedspectrum beta-lactamase-producing E. coli and Klebsiella pneumoniae in children at University Pediatric Clinic in Skopje. MJMS 2009; 2: 36-41.

11. Kaftandzieva A, Kotevska V, Cekovska Z, Jankoska G, Kjurcik-Trajkovska B, Petrovska M. Prevalence and spread of extended-spectrum beta-lactamase-producing E. coli and Klebsiella pneumoniae at University Clinics in Skopje. Acta Morphol. 2009; 6: 66-71.
12. Kaftandzieva A, Trajkovska-Dokic E, Panovski N. Prevalence and molecular characterization of extended spectrum beta-lactamases (ESBL)-producing Escherichia coli and Klebsiella pneumoniae. Contributions, Sec Biol Med Sci, MASA, XXXII/2, 2011: 129-141.

13. Kim J, Jeon S, Lee B, Park M, Lee H, Lee J, Kim S. Rapid detection of extended spectrum $\beta$-lactamase (ESBL) for Enterobacteriaceae by use of a multiplex PCR-based method. Infection and Chemotherapy. 2009; 41: 181-184.

14. Colom K, Perez J, Alonso R, Fernandez-Aranguiz A, Larino E, Cisterna RSimple and reliable multiplex PCR assay for detection of bla $\mathrm{T}_{\mathrm{TEM}}$, bla $\mathrm{SHV}_{\mathrm{SHV}}$ and bla $\mathrm{O}_{\mathrm{OXA}}$ 1 genes in Enterobacteriaceae. FEMS Microbiology Letters. 2003; 223: 147-151.

15. Jemima SA, Vergese S. Multiplex PCR for bla $\mathrm{T}_{\mathrm{TEM}} \&$ bla $_{\mathrm{SHV}}$ in the extended spectrum beta lactamase (ESBL) producing Gram-negative isolates. Indian J Med Res. 2008; 128: 313-317.

16. Shahcheraghi F, Nasiri S, Noveiri H. The survey of genes encoding beta-lactamases in Escherichia coli resistant to beta-lactam and non-beta-lactam antibiotics. Iran J Basic Med Sci. 2010; 13: 230-237.

17. Tofteland S, Haldorsen B, Dahl KH, Simonsen GS, Steinbakk M, Walsh TR, Sundsfjord A. Norwegian ESBL Study Group. Effects of phenotype and genotype on methods for detection of extended-spectrum$\beta$-lactamase-producing clinical isolates of Escherichia coli and Klebsiella pneumoniae in Norway. J Clin Microbiol. 2007; 45: 199-205.

18. Sorlozano A, Gutierrez J, Luna JD, Soto MJ, Piedrola $G$. In vitro activity of $\beta$-lactam and non- $\beta$-lactam antibiotics in extended-spectrum $\beta$-lactamase-producing clinical isolates of Escherichia coli. Diagn Microbiol Infect Dis. 2006; 54: 135-139.

19. Navarro F, Miro E, Mirelis B. Interpretive reading of the antibiogram of enterobacteria. Enferm Infect Microbiol Clin. 2002; 20: 225-234.

20. Jain A, Mondal R. TEM \& SHV genes in extended spectrum $\beta$-lactamase producing Klebsiella species \& their antimicrobial resistance pattern. Indian $\mathrm{J}$ Med Res. 2008; 128: 759-764.

21. Perez F, Endimiani A, Hujer K, Bonomo R. The continuing challenge of ESBLs. Curr Opin Pharmacol. 2007; 7: 459-469.

22. Hadziyannis E, Tuohy M, Thomas L, Procop GW, Washington JA, Hall GS. Screening and confirmatory testing for extended spectrum $\beta$-lactamases (ESBL) in Escherichia coli, Klebsiella pneumoniae and Klebsiella oxytoca clinical isolates. Diagn Microbiol Infect Dis. 2000; 36: 113-117.

23. Nordmann P, Naas T, Poirel L. Global spread of carbapenemase-producing Enterobacteriaceae. Emerg Infect Dis. 2011; 17: 1791-98.

24. Nordmann P, Dortet L, Poirel L. Carbapenem resistance in Enterobacteriaceae: here is the storm! Trends Mol Med. 2012; 18: 263. 
25. Tzouvelekis LS et al. Carbapenemases in Klebsiella pneumoniae and other Enterobacteriaceae: an evolving crisis of global dimensions. Clin Microbiol Rev. 2012; 25: 682 .

Резиме

\section{КОРЕЛАЦИЈА МЕЃУ ГЕНОТИПОВИТЕ НА ЕSВL-ПОЗИТИВНИТЕ СОЕВИ \\ НА E. COLI И KLEBSIELLA PNEUMONIAE И РЕЗИСТЕНЦИЈАТА КОН РАЗЛИЧНИ АНТИМИКРОБНИ СРЕДСТВА}

Ана Кафтанџиева, Елена Трајковска-Докиќ, Весна Котевска, Жаклина Цековска, Гордана Јанкоска

Институт за микробиологија и паразитологија, Медицински факултет,

Универзитет „Св. Кирил и Методиј“, Скопје, Р. Македонија

Целта на студијата е да се согледа поврзаноста на резистенцијата кон антимикробните средства со гените што кодираат различни типови бета-лактамази кај ESBL-позитивните соеви на E. coli и Klebsiella pneumoniae-Kp.

Материјал и методи: Со примена на фенотипски тестови (ESBL-сет и автоматизиран Vitek 2 систем), беа детектирани вкупно 251 ESBL-позитивен coj на E. coli и $K p$, кои беа изолирани од различни примероци (урина, трахеален аспират, брис од рана, хемокултура) од пациенти хоспитализирани во Универзитетските клиники во Скопје. Vitek беше употребен и за одредување на осетливоста (одредување на МИК \$ минимални инхибиторни концентрации) кон 17 антимикробни агенси. Со Мултиплекс ПВР беа детектирани гените за продукција на ESBL кај 100 ESBL-позитивни соеви, селектирани по случаен избор.

Резултати: Повеќето генетски типизирани ESBL-позитивни изолати (61\%) поседуваа два или повеќе гени за продукција на беталактамази и кај нив постоеше поголема антимикробна резистенција, споредено со изолатите кои поседуваа по еден ген. Изолатите со $\geq 3$ гени покажуваа висок процент на резистенција кон употребените бета-лактамски и не-беталактамски антибиотици. Степенот на резистенција кон третогенерациските цефалоспорини кај овие изолати беше висок (МИК $\geq 64)$. Повеќето ESBL-позитивни изолати беа порезистентни на цефотаксим отколку на цефтазидим.

Заклучок: Идентификацијата на гените, која е неопходна за следење на нивната трансмисија во болничката средина, како и следењето на антибиотската резистенција е важно за надминување на проблемите поврзани со ESBLпродуцирачки бактерии.

Клучни зборови: ESBL, Escherichia coli, Klebsiella pneumoniae, антибиотска резистенција. 